\title{
The Influence of Problem-Solving Learning Model and Student Learning Motivation on Mathematical Reasoning Ability
}

\author{
Ismail Djakaria $^{1}$, Febri Harun ${ }^{1}$, Sarson W. Dj Pomalato ${ }^{1}$ \\ Email: iskar@ung.ac.id \\ ${ }^{1}$ Gorontalo State University, Indonesia
}

Received: May 17, 2021

Revised: June 10, 2021

Accepted: June 20, 2021

\begin{abstract}
This study aims to determine whether the mathematical reasoning ability of students who are taught by the problem-solving learning model is effective in terms of the learning motivation of class VII students of SMP Negeri 4 Gorontalo. This type of research is Quasi Experiment with Treatment by level $2 \times 2$ design using two-way analysis test and Tukey test. The results showed that the mathematical reasoning ability of students who had intrinsic learning motivation in problem-solving learning was 84.13 and the mathematical reasoning ability of students who had intrinsic learning motivation in conventional learning was 67.21. This can also be proven through a test with a significant level of $5 \%$ and $\mathrm{df}=127$ indicating $t>t_{(1,127)(0.05)}$. Obtained $t=4.232$ for $\alpha=0.05$ obtained $t_{(1,127)(0.05)}=2.80$ Thus, the reasoning abilities of students who have intrinsic learning motivation are taught by problem-solving learning more effectively than the reasoning abilities of students who have intrinsic learning motivation are taught by conventional learning.
\end{abstract}

Keywords: Mathematical Reasoning Ability, Problem-Solving Learning Model, Learning Motivation

\section{Introduction}

Most mathematics learning in schools involves mathematical reasoning abilities. If reasoning abilities are not developed in students, then for students mathematics becomes a material that only follows procedures and imitates examples without knowing their meaning. According to Sapa'at (2020) that mathematics is a tool to develop a way of thinking, that's why mathematics is indispensable for everyday life. The Education Unit Level Curriculum (BSNP 2016) contains the objectives of learning mathematics, namely; (1) Mastering mathematical concepts, explaining the relationship between concepts and applying concepts, flexibly, carefully, effectively, and precisely, in problem solving; (2) Using reasoning in patterns and traits, performing mathematical manipulations in making generalizations, compiling proofs, or generating mathematical ideas and statements; (3) Solving problems includes designing mathematical models, the ability to understand problems, complete models and interpret the solutions obtained; (4) Convey ideas with symbols, tables, diagrams, or other media in clarifying a problem or situation; (5) Mastering the attitude of taking into account the usefulness of mathematics in life, namely having attention, curiosity, and a tenacious and confident attitude in problem solving and an interest in learning mathematics.

The curriculum objectives in the joint decision of the Minister of Education and Culture, the Minister of Religion, the Minister of Health, and the Minister of Home Affairs of the Republic of Indonesia regarding Guidelines for the Implementation of Learning in the 2020/2021 Academic Year and the 2020/2021 Academic Year during the 2019 Coronavirus Disease (COVID-19) pandemic period include 4 competencies, including knowledge competence, 
spiritual attitudes, social attitudes, and skills. Knowledge Competencies are described as follows (1) Understanding knowledge such as factual, conceptual, and procedural based on students' curiosity about science, art, culture related to technological phenomena, and visible events, (2) Processing, trying, and presenting in concrete domains such as parsing, assembling, modifying, using, and creating abstract domains such as reading, counting, drawing, writing, and composing according to what is learned in school and other sources that are similar in point of view or theory (Usman, 2013).

This is supported by the results of an international survey on the ability of Indonesian children aged 15 years in mathematics released by PISA in 2018 showing that students' abilities in mathematics achieved an average score of 379, with an average OECD score of 487 (Kemdikbud, 2019). In line with this, the national exam scores obtained by students at SMP Negeri 4 Gorontalo are still below the average at the district, provincial and national levels.

According to the results of observations on students of SMP Negeri 4 Gorontalo Even Semester 2020/2021, it is known that the mathematics National Examination (UN) scores of students from 2015 to 2019 are still low compared to other subjects, this can be seen in the following table.

Table 1. Achievement of national examination scores at SMP Negeri 4 Gorontalo in 2015 2019

\begin{tabular}{|c|c|c|c|c|c|c|}
\hline Year & \multirow{2}{*}{$\begin{array}{c}\text { Number of } \\
\text { participant }\end{array}$} & \multicolumn{4}{|c|}{ Average value on test topic } & Total \\
\cline { 3 - 6 } & & $\begin{array}{c}\text { Topic of } \\
\text { Indonesian }\end{array}$ & $\begin{array}{c}\text { Topic of } \\
\text { English }\end{array}$ & $\begin{array}{c}\text { Topic of } \\
\text { Mathematics }\end{array}$ & $\begin{array}{c}\text { Topic of Natural } \\
\text { Science }\end{array}$ & \\
\hline 2015 & 207 & 64.68 & 42.45 & 34.61 & 40.17 & 45,48 \\
\hline 2016 & 203 & 62.45 & 38.52 & 28.79 & 39.1 & 42,22 \\
\hline 2017 & 211 & 59.45 & 37.87 & 33.98 & 39.3 & 42,65 \\
\hline 2018 & 218 & 60.5 & 42.03 & 32.65 & 39.68 & 43,72 \\
\hline 2019 & 223 & 59.04 & 42.04 & 37.86 & 40.04 & 44,75 \\
\hline
\end{tabular}

Source: https://hasilun.puspendik.kemdikbud.go.id/)

Table 1 shows that students have not been able to optimize their ability to solve mathematical problems. This happens because they already think mathematics is a difficult and scary subject so that their behavior during learning takes place varies, some students support their chins and put their heads on the table, some play alone / chat with other friends, and take notes. teacher's explanation, so that students do not look enthusiastic in participating in learning. Class conditions are immediately silent when the teacher asks questions to students or is given assignments so that the interaction between students and teachers is not optimal. It can be seen that the learning process, in general, tends to limit the involvement of students, more teacher dominance as a result, students wait for more for teacher direction than seek and find the knowledge, skills, or attitudes they need (Davies, 2000; Djamarah \& Zain, 2010). There are still many teachers who use conventional learning, such as expository, question and answer, lectures, assignments, and exercises. Conventional learning does not provide opportunities for students to be active, because the learning tends to be one-way which is only dominated by the teacher. As a result of these conditions, students find it difficult to solve problems or questions given by the teacher, so that the expected learning outcomes do not meet the desired requirements and targets. Based on the results of observations, it is also found that factors that are thought to influence learning outcomes are lack of motivation from teachers, monotonous learning, presentation of material and the use of media in learning is less varied, and lack of teacher guidance to direct students to be more active and able to achieve learning success. 
To be able to carry out a learning activity that we want, first of all, there must be an incentive to carry out these activities. In a sense, to do something there must be motivation. Likewise, in the learning process, students must have the motivation to take part in ongoing learning activities. If they have strong motivation, students will show their interests, activities, and participation in participating in learning activities that are being carried out. Given the importance of the role of motivation in one's life and especially in the world of education, all educators should also pay attention to all things that can develop good motivation for their students. Parents and teachers can organize and create an atmosphere that can generate healthy competition by creating a sense of satisfaction with the achievements that have been achieved, getting them used to discussing an opinion or ideals and fostering good motivation, and showing them that achieving a goal or not is very important. depending on what motivation drives to achieve that goal (Uno, 2017).

Extrinsic motivation or motivation that comes from outside needs to be given to provoke the emergence of existing motivation, namely intrinsic motivation, in the form of desire and desire to succeed and encouragement of learning needs, hopes for ideals. Especially in the family environment, parents must be role models for their children. With the motivation, a child will be motivated and directed in learning, so that they will get good mathematical reasoning and be eager to follow the teaching and learning process (Brodie, 2010; Kasmadi \& Sunariah, 2017; Hamdani, 2017; Susanto; 2018).

Thobroni (2016) stated that the efforts made by the teacher were not solely carried out in a short time. Because learning is a repetitive learning method that causes a conscious change in behavior and tends to be consistent. We can read the same thing in Cahyo (2013), Sumantri (2015), and Mulyatna et al (2019).

It is hoped that with the interaction between motivation, material objectives, and learning models, students' reasoning abilities in solving mathematical problems can be obtained as much as possible. Based on the explanation above, the researcher is interested in conducting research entitled: "The Effect of Problem Solving Learning Model and Students' Learning Motivation on Mathematical Reasoning Ability"

\section{Methods}

This research was conducted at SMP Negeri 4 Gorontalo, West City sub-district, Gorontalo City, Gorontalo Province. This research was conducted in the even semester of the 2020/2021 school year starting from January 2021 to May 2021, which includes learning activities by applying problem-solving learning models and conventional learning, data collection, and data processing, to the preparation of research reports. This type of research is quasi-experimental research (Quasi Experiment) using treatment by level 2 x 2 design which involves several variables, namely: (1) mathematical reasoning ability as the dependent variable $(Y)$; (2) learning model $(A)$ as an independent variable treatment consisting of problem-solving learning model $\left(A_{1}\right)$ and conventional learning $\left(A_{2}\right)$; and (3) students' learning motivation $(B)$ as moderator variable consisting of intrinsic learning motivation $\left(B_{1}\right)$ and extrinsic learning motivation $\left(B_{2}\right)$. In general, the data in this study consist of (1) data on the results of mathematical reasoning abilities, (2) data on student learning motivation. Collecting data for mathematical reasoning skills using a written test instrument in the form of a description and learning motivation using a non-test instrument, namely a questionnaire. In this study, there is only one instrument developed by the researcher, namely the instrument of students' mathematical reasoning abilities in the form of an essay test (description). Meanwhile, the learning motivation instrument used to classify intrinsic learning motivation and extrinsic learning motivation was in the form of a questionnaire/questionnaire. The data analysis used in this study is related to the requirements tests in the form of homogeneity analysis and normality analysis. And another 
analysis is in the form of a two-way analysis of variance (ANOVA 2x2) to test the research hypothesis with the $F$ test at a significance level of alpha $(\alpha)=0.05$.

\section{Results and Discusssion}

In general, the description of the eight data groups of mathematical reasoning abilities can be presented in the following table:

Table 2. Description of mathematical reasoning ability data

\begin{tabular}{|c|c|c|c|c|c|c|c|c|}
\hline Data & $\boldsymbol{N}$ & $\begin{array}{c}\text { Score } \\
(\mathbf{m i n})\end{array}$ & $\begin{array}{c}\text { Score } \\
(\mathbf{m a x})\end{array}$ & $\begin{array}{c}\text { Mean } \\
(\overline{\boldsymbol{X}})\end{array}$ & $\begin{array}{c}\text { Mode } \\
\left(\boldsymbol{M}_{\boldsymbol{o}}\right)\end{array}$ & $\begin{array}{c}\text { Median } \\
\left(\boldsymbol{M}_{\boldsymbol{e}}\right)\end{array}$ & $\begin{array}{c}\text { Deviation } \\
\text { standard }(\boldsymbol{s})\end{array}$ & $\begin{array}{c}\text { Variances } \\
\left(\boldsymbol{s}^{\mathbf{2}}\right)\end{array}$ \\
\hline$A_{1}$ & 64 & 28 & 108 & 74.75 & 82.42 & 76.7 & 16.54 & 273.71 \\
\hline$A_{2}$ & 64 & 32 & 98 & 70.25 & 64.98 & 70.45 & 14.75 & 217.46 \\
\hline$B_{1}$ & 42 & 32 & 108 & 74.45 & 82.1 & 75.5 & 16.84 & 283.67 \\
\hline$B_{2}$ & 86 & 28 & 98 & 69.05 & 67.72 & 70 & 15.71 & 245.66 \\
\hline$A_{1} B_{1}$ & 23 & 49 & 108 & 83.5 & 95.17 & 86 & 14.77 & 218.18 \\
\hline$A_{1} B_{2}$ & 41 & 28 & 92 & 67.07 & 78.57 & 69.67 & 14.51 & 210.57 \\
\hline$A_{2} B_{1}$ & 19 & 32 & 86 & 65.37 & 69.39 & 67.25 & 13.38 & 179.02 \\
\hline$A_{2} B_{2}$ & 45 & 36 & 98 & 68.2 & 76.64 & 68.69 & 16.12 & 259.94 \\
\hline
\end{tabular}

Note:

$A_{1}$ : Scores of students' mathematical reasoning abilities who are taught by the problemsolving learning model

$A_{2}$ : Score of students' mathematical reasoning abilities taught by conventional learning

$B_{1}$ : Scores of students' mathematical reasoning abilities who have intrinsic learning motivation

$B_{2}$ : Scores of students' mathematical reasoning abilities who have extrinsic learning motivation

$A_{1} B_{1}$ : Score of students' mathematical reasoning abilities who are taught problem-solving learning models and have intrinsic learning motivation

$A_{1} B_{2}$ : Score of students' mathematical reasoning abilities who are taught Problem-solving learning models and have extrinsic learning motivation

$A_{2} B_{1}$ : Score of students' mathematical reasoning abilities who are taught conventional learning and have intrinsic learning motivation

$A_{2} B_{2}$ : Score of students' mathematical reasoning abilities who are taught conventional learning and have extrinsic learning motivation

Two-way analysis of variance (ANOVA $2 \times 2$ ) is a calculation technique (parametric statistics) which aims to investigate two effects, namely the main effect and the interaction effect. The "main" effect here is the effect of differences in problem-solving learning models and conventional learning on mathematical reasoning abilities, and also the effect of differences in learning motivation on mathematical reasoning abilities. The effect of "interaction" in question is the effect of the interaction between learning and student motivation on mathematical reasoning abilities. The results of the 2-way ANOVA calculation can be briefly seen in the following table. 
Table 3. Summary of ANOVA of results for mathematical reasoning ability data

\begin{tabular}{|c|c|c|c|c|c|}
\hline Source & $\begin{array}{c}\text { Sum } \\
\text { squared } \\
(\mathbf{S S})\end{array}$ & $\begin{array}{c}\text { Degrees of } \\
\text { freedom } \\
(\mathbf{d f})\end{array}$ & $\begin{array}{c}\text { Mean } \\
\text { squared } \\
(\mathbf{M S})\end{array}$ & $\boldsymbol{F}$ & $\begin{array}{c}\boldsymbol{F} \text { table } \\
(\boldsymbol{\alpha = 0 . 0 5})\end{array}$ \\
\hline Learning $(A)$ & 666.125 & 1 & 666.125 & 4.004 & 3.92 \\
\hline Learning motivation $(B)$ & 1518.917 & 1 & 1518.917 & 9.131 & 3.92 \\
\hline $\begin{array}{c}\text { Interaction of Learning and } \\
\text { Learning Motivation }(A B)\end{array}$ & 2405.808 & 1 & 2405.808 & 14.462 & 3.92 \\
\hline Error $(d)$ & 20626.87 & 124 & 166.35 & - & - \\
\hline Total $(T)$ & $\mathbf{2 5 2 1 7 . 7 2}$ & $\mathbf{1 2 7}$ & $\mathbf{4 7 5 7 . 2}$ & & \\
\hline
\end{tabular}

From the results of calculations using the $\mathrm{F}$ test, it was obtained which turned out to be greater than the value at a significant level with the numerator's degree of freedom $(d f)=1$ and the denominator's degree of freedom $(d f)=127$. This means the null hypothesis which states that there is no interaction between the learning model and students' learning motivation on ability. mathematical reasoning is rejected. Thus the alternative hypothesis which states that there is an interaction effect between learning models and learning motivation on mathematical reasoning abilities is accepted. The effect of the interaction can be described in figure below.

\section{SCORE AVERAGE OF MATHEMATICAL REASONING ABILITY}

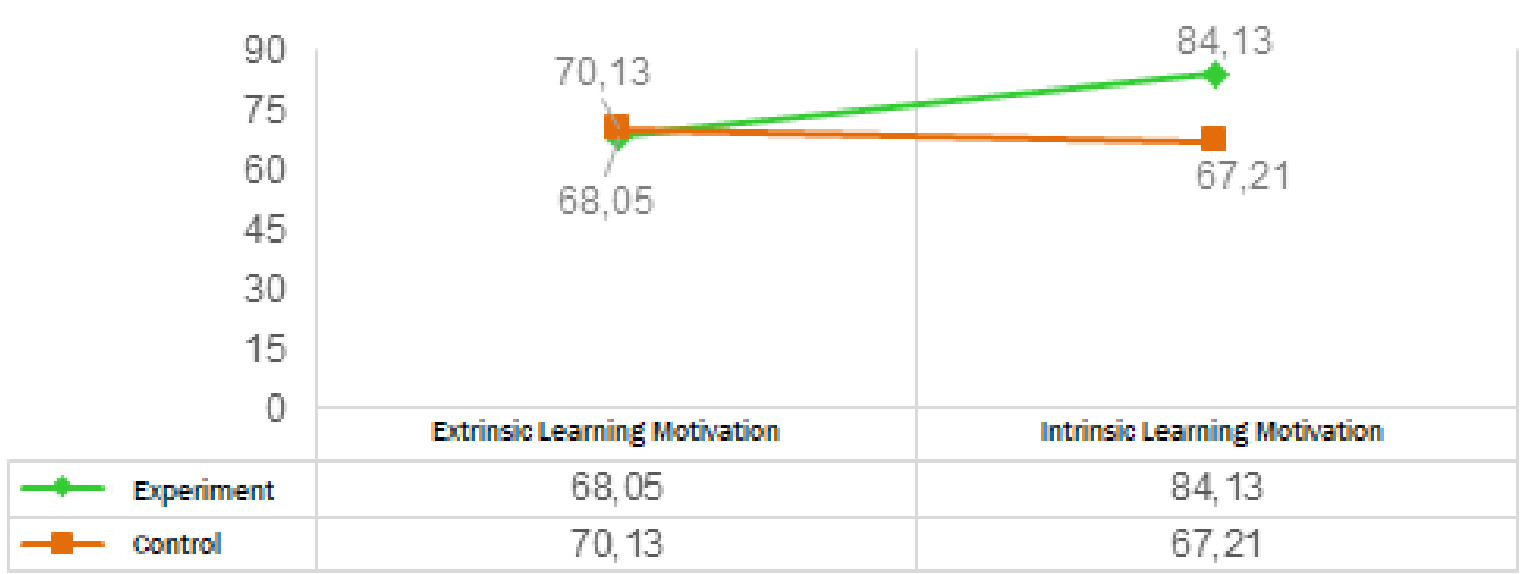

Figure 1. Data Interaction Curve between Learning Models and Students' Learning Motivation on Mathematical Reasoning Ability

The results of further test calculations using $t$-test for the two groups of subjects were compared to test the third and fourth hypotheses.

Table 4. Summary of paired $t$-test results

\begin{tabular}{|c|c|c|c|c|c|}
\hline No & Group & $t$ & $t_{0.01}$ & $t_{0.05}$ & Conclusion \\
\hline 1 & $A_{1} B_{1}$ and $A_{2} B_{1}$ & 4.2321 & 3.70 & 2.80 & significant \\
\hline 2 & $A_{1} B_{2}$ and $A_{2} B_{2}$ & 0.7471 & 3.70 & 2.80 & not significant \\
\hline
\end{tabular}

The third hypothesis proposed in this study is "The ability of mathematical reasoning applied by the problem-solving learning model is higher than that applied by the conventional approach to students who have intrinsic learning motivation". From the test results using the $t$-test obtained $t=4.2321$ and $t_{0.05}=2.80$. According to this information, the null hypothesis which states that the mathematical reasoning abilities of students who have intrinsic learning 
motivation who are taught problem-solving learning models are lower or the same as those taught by conventional learning is rejected. This means that the alternative hypothesis which states that the mathematical reasoning ability applied by the problem-solving learning model is higher than that applied with the conventional approach to students who have intrinsic learning motivation.

This can also be seen in the acquisition of the average score for the mathematical reasoning ability of the group of students who have intrinsic learning motivation who is taught problemsolving learning model $\left(\bar{X}_{A_{1} B_{1}}\right)$ of 84.13 which is higher than the group of students who are taught conventional learning $\left(\bar{X}_{A_{2} B_{1}}\right)$ of 67.21 . This finding confirms the third hypothesis proposed. Thus, it can be said that the problem-solving learning model is more suitable to be taught to groups of students who have intrinsic learning motivation.

\section{Differences in mathematical reasoning ability of students who are taught the problem solving learning model and the conventional learning model}

From the results of data analysis, it was found that the mathematical reasoning ability of students who were taught with problem-solving learning models was higher than students who were taught by conventional learning. This is indicated by the value that turned out to be significant. In the results of these calculations, it was found that the average mathematical reasoning ability of students who were taught using problem-solving learning models was higher than the mathematical reasoning abilities of students who were taught using conventional learning, on rectangular and triangular materials. So that it can be concluded that there is an effect of problem-solving learning models on students' mathematical reasoning abilities on the material of rectangles and triangles.

Examples of student work results in taking tests in classes that apply problem-solving learning models with question 1 :

"Dimas is a farmer who owns a plot of land that is $24 \mathrm{~m}$ long and $15 \mathrm{~m}$ wide. The land will be made into a rhombus-shaped pond with diagonals of $9 \mathrm{~m}$ and $12 \mathrm{~m}$ long, respectively, while the rest will be planted with banana trees. How much area of land is Dimas planted with banana trees?"

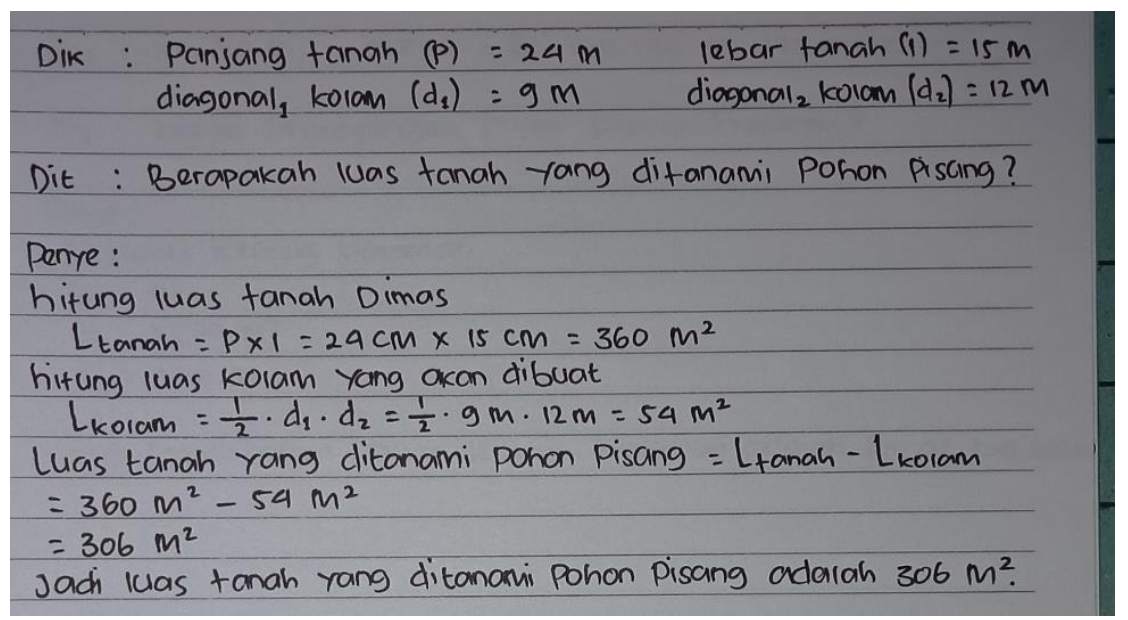

Figure 2. The results of student work taught by the problem-solving learning model

Examples of student work result in taking tests in classes that apply problem-solving learning models with question 2 .

"Vincent's courtyard is a square with a side measuring 80 meters. Around the yard, a fence will be installed for Rp. 135,000.00 per meter. How much will it cost to install the fence?" 


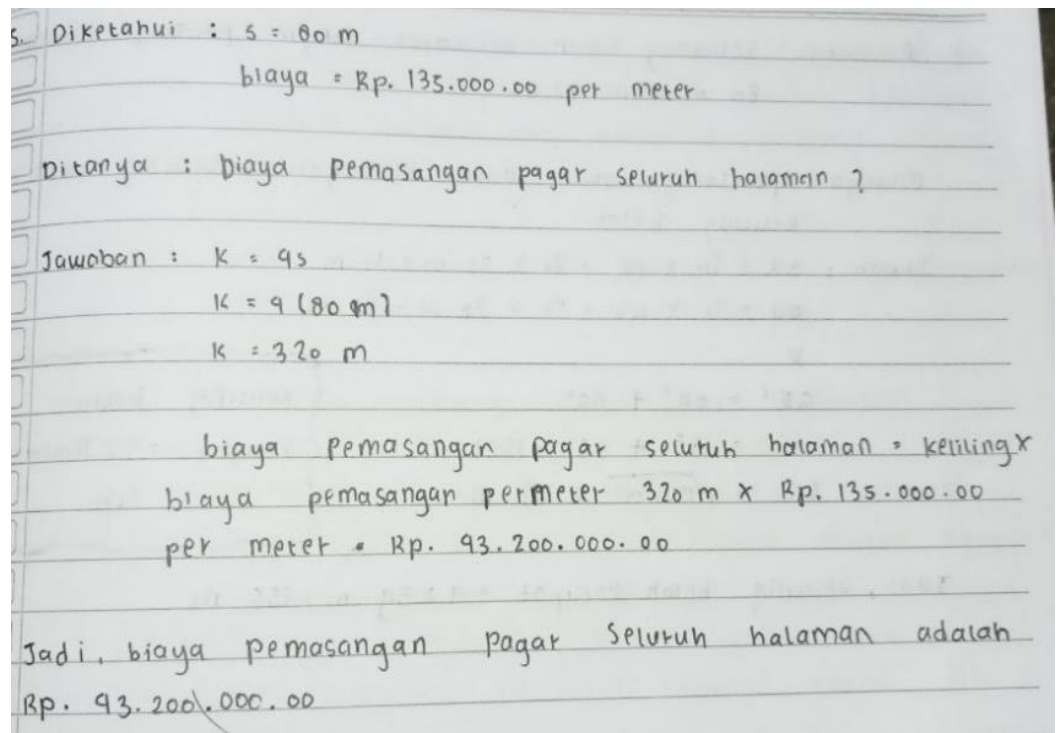

Figure 3. The results of student work taught by the problem-solving learning model

It can be seen from the example questions above that students have been able to solve the questions correctly and precisely. The solutions made by students show that students can propose conjectures and ideas by understanding the types of questions that must be answered and can choose the right formula that can describe the meaning of the problem, namely using the formula for the perimeter and area of a rectangle to solve the problem on the question. Next, students compile evidence so that the problem can be solved by describing the formula for the perimeter and area of the rectangle to prove it and students also manipulate the formula into an equation to make it easier for students to solve the problems in the problem. In manipulating the problems, the students gave statements that conclude that the area of land planted with banana trees is $306 \mathrm{~m}^{2}$ and the cost of installing a fence around the yard is Rp. 43,200,000.00. It can be said that from these questions, students have mastered the four indicators of mathematical reasoning abilities, namely being able to propose conjectures and ideas in mathematical form orally, in writing, pictures, and graphs, able to compile evidence and provide evidence of solutions, able to perform mathematical manipulations and be able to conclude.

\section{The effect of interaction between learning models and students' learning motivation on mathematical reasoning ability}

Based on the results of the statistical analysis regarding mathematical reasoning abilities that are mutually influenced by two independent variables in this study, which causes the interaction effect of learning models and cognitive styles. This can be seen in the ANOVA, we obtained $F$ $=14.462>F_{(1,108)(0.05)}$, then $\mathrm{H}_{0}$ is rejected. This means that there is a significant interaction effect between groups of students who are taught problem-solving learning models and groups of students who are taught conventional learning with learning motivation on mathematical reasoning abilities. The interaction proves that each learning model has a different effect on mathematical reasoning abilities when applied to groups of students who have certain learning motivations.

The analysis above can be explained that in the application of the learning model it is necessary to consider students' learning motivation because each learning model has different characteristics so that it is necessary to match the learning motivation with the learning model used. the application of learning models that are following students' specific learning 
motivations is expected to encourage the achievement of high mathematical reasoning abilities. On the other hand, if the application of the learning model is not adjusted to the specific learning motivation of students, it will result in the achievement of low or not optimal mathematical reasoning abilities.

The differences in mathematical reasoning ability of students who are taught with problem-solving learning models and those taught with conventional learning towards students who have intrinsic learning motivation.

From the results of data analysis, it is found that there are differences in the mathematical reasoning abilities of students who have intrinsic learning motivation who are taught problemsolving learning models and conventional learning. This is indicated by the value of $t=4.2321$ that turned out to be significant. These findings indicate that the problem-solving learning model is very suitable to be taught to students who have intrinsic learning motivation so that they can develop mathematical reasoning abilities.

Students with intrinsic learning motivation are better able to express ideas or ways of thinking systematically, creatively, and critically in solving mathematical problems and in drawing conclusions or decisions. This will certainly make it easier for them to work on questions that require mathematical reasoning activities.

The differences in mathematical reasoning ability of students who are taught with problem solving learning models and those taught with conventional learning towards students who have extrinsic learning motivation.

From the results of data analysis, it was found that the average score of students' mathematical reasoning abilities with extrinsic learning motivation taught by the Problem-solving learning model $\left(\bar{X}_{A_{1} B_{2}}\right)$ was 68.05 lower than that taught by the conventional learning model $\left(\bar{X}_{A_{2} B_{2}}\right)$ of 70.13 , but this difference was not significant. This is indicated by the $t=0.7471$ which was not significant. This finding shows that the mathematical reasoning ability of students with extrinsic learning motivation who is taught by the Problem-solving learning model is not different from that taught by the conventional learning model. Since the students who have extrinsic learning motivation tend to be socially oriented and prioritize external motivation and reinforcement. A problem-solving learning model that emphasizes group work, especially in completing tasks can lead to high social interaction.

\section{Conclusion}

Based on the results of hypothesis testing and discussion of research results, it can be concluded that; (1) The mathematical reasoning ability of students who are taught problem-solving learning models is higher than students who are taught conventional learning; (2) There is an interaction effect between learning models and learning motivation on mathematical reasoning abilities; (3) In the group of students who have intrinsic learning motivation, the mathematical reasoning ability of students taught by problem-solving learning models is higher than students who are taught by conventional learning; (5) In the group of students who have extrinsic learning motivation, students' mathematical reasoning abilities are taught by problem-solving learning models the same as students who are taught by conventional learning.

\section{References}

Brodie, K. (2009). Teaching mathematical reasoning in secondary school classrooms (Vol. 775). Springer Science \& Business Media.

BSNP. (2016). Panduan Penyusunan Kurikulum Tingkat Satuan Pendidikan Jenjang Pendidikan dasar dan Menengah. Jakarta BSNP 
Cahyo, A. N. (2013). Panduan Aplikasi Teori-teori Belajar Mengajar. Yogyakarta: Diva Press

Davies, I. (2000). Pengelolaan Belajar, Terj. Dari The Manajement of Learning oleh Sudarsono Sudirdjo, (nd ed). Jakarta: Rajawali Pres,

Djamarah, B \& Zain, A. (2010). Strategi Belajar Mengajar. Jakarta: Rieneke Cipta.

Hamdani. (2017). Strategi Belajar Mengajar. Bandung: CV Pustaka Setia.

Kasmadi \& Sunariah. (2017). Panduan Modern Penelitian Kuantitatif. Bandung: Alfabeta

Mulyatna. F, Nurrahmah. A, \& Seruni. (2019). The Influence of Learning Model and Learning Motivation Towards Mathematical Reasoning Abilities in Junior High School. Advances in Social Science, Education and Humanities Research, (512).

Sumantri, M. (2015). Strategi Pembelajaran Teori dan Praktik di Tingkat Pendidikan Dasar. Jakarta: Raja Grafindo Persada

Susanto, A. (2018). Teori Belajar dan Pembelajaran di Sekolah Dasar. Terintegratif. Jakarta: Prestasi Pustakaraya.

Thobroni, M. (2016). Belajar dan Pembelajaran: Teori dan Praktik. Bandung: Ar-Ruzz Media

Uno, H. (2017). Teori Motivasi dan Pengukurannya: analisis di bidang pendidikan. Jakarta: Bumi Aksara

Usman, E. (2013). Meningkatkan Penalaran Siswa SMP Melalui Pendekatan Kontekstual. Prosiding Seminar Nasional Pendidikan Matematika Volume 1, Tahun 2013. ISSN 977-2338831. Bandung: Sekolah Tinggi Keguruan dan ilmu Pendidikan (STKIP) Siliwangi Bandung 